\title{
New Insights Into the Seasonal Movement Patterns of Shortfin Mako Sharks in the Gulf of Mexico
}

\author{
Kesley J. Gibson*, Matthew K. Streich, Tara S. Topping and Gregory W. Stunz \\ Harte Research Institute for Gulf of Mexico Studies, Texas A\&M University - Corpus Christi, Corpus Christi, TX, United States
}

OPEN ACCESS

Edited by:

Yannis Peter Papastamatiou, Florida International University,

United States

Reviewed by:

Neil Hammerschlag,

University of Miami, United States

Tobey H. Curtis,

National Oceanic and Atmospheric Administration (NOAA), United States

*Correspondence:

Kesley J. Gibson

Kesley.Gibson@tamucc.edu

Specialty section:

This article was submitted to

Marine Megafauna,

a section of the journal

Frontiers in Marine Science

Received: 29 October 2020

Accepted: 04 January 2021

Published: 26 January 2021

Citation:

Gibson KJ, Streich MK,

Topping TS and Stunz GW (2021)

New Insights Into the Seasonal Movement Patterns of Shortfin Mako

Sharks in the Gulf of Mexico.

Front. Mar. Sci. 8:623104.

doi: 10.3389/fmars.2021.623104
Highly mobile apex predators such as the shortfin mako shark (mako shark; Isurus oxyrinchus) serve an important role in the marine ecosystem, and despite their declining populations and vulnerability to overexploitation, this species is frequently harvested in high abundance in both commercial and recreational fisheries. In 2017, the North Atlantic stock was deemed overfished and to be undergoing overfishing and was recently listed in CITES Appendix II. Effective management of this species can benefit from detailed information on their movements and habitat use, which is lacking, especially in the Gulf of Mexico, a potential mating and parturition ground. In this study, we used satellite telemetry to track the movements of mako sharks in the western Gulf of Mexico between 2016 and 2020. In contrast to previous studies that have primarily tagged juvenile mako sharks (> $80 \%$ juveniles), $~ 80 \%$ of sharks tagged in this study (7 of 9) were presumed to be mature based on published size-at-maturity data. Sharks were tracked for durations ranging from 10 to 887 days (mean $=359$ days; median $=239$ days) with three mature individuals tracked for $>2$ years. Mako sharks tagged in this study used more of the northwestern Gulf of Mexico than reported in previous movement studies on juveniles, suggesting potential evidence of size segregation. While one mature female remained in the Gulf of Mexico over a >2year period, predominantly on the continental shelf, two mature males demonstrated seasonal migrations $\sim 2,500 \mathrm{~km}$ from the tagging location off the Texas coast to the Caribbean Sea and northeastern United States Atlantic coast, respectively. During these migrations, mako sharks traversed at least 12 jurisdictional boundaries, which also exposed individuals to varying levels of fishing pressure and harvest regulations. Movement ecology of this species, especially for mature individuals in the western North Atlantic, has been largely unknown until recently. These data included here supplement existing information on mako shark movement ecology and potential stock structure that could help improve management of the species.

Keywords: shortfin mako, population connectivity, Gulf of Mexico, sharks, migration

\section{INTRODUCTION}

Highly migratory species often fill the role of apex predator in marine ecosystems, but many populations are declining globally which can have cascading effects on lower trophic levels (Estes et al., 2011; Dulvy et al., 2014; Hammerschlag et al., 2019). These highly mobile species create a unique management problem given their wide movement ranges, as they often cross many 
jurisdictional boundaries, exposing them to varying degrees of protection (Rooker et al., 2019). Given their high potential for movement over very large spatial scales, identifying their particular habitat requirements can be very challenging. Furthermore, highly migratory species, including oceanic sharks, are often caught in commercial and recreational fisheries (Block et al., 2011; Francis et al., 2019) and are vulnerable to overexploitation due to their life history characteristics, which include long lifespans, late maturity, and long reproductive cycles (Pratt and Casey, 1983; Mollet et al., 2000; Cortés et al., 2010). Conservation and rebuilding of these declining species can benefit from species-specific knowledge on movements and habitats needed to complete their life cycles (Hays et al., 2019).

One such species is the shortfin mako (Isurus oxyrinchus; hereafter mako shark), which are pelagic, fast-swimming, sharks found in tropical and temperate waters circumglobally. Mako sharks are valued catches in both commercial and recreational fisheries (Campana et al., 2005), and while some directed fisheries exist, mako sharks are often caught as bycatch in commercially important fisheries due to their overlapping habitat with these species (e.g., billfish, tuna; Queiroz et al., 2016). Although $60-80 \%$ of longline-hooked mako sharks are alive at haul back (Campana, 2016; Campana et al., 2016; Queiroz et al., 2016), they are typically harvested because of their highquality meat and valuable fins (Clarke et al., 2006; International Commission for the Conservation of Atlantic Tunas [ICCAT], 2013). In the Atlantic Ocean, Byrne et al. (2017) reported that $30 \%$ of their tagged juvenile mako sharks were captured in fisheries suggesting that mako sharks were likely being overexploited, and in 2017, the International Commission for the Conservation of Atlantic Tunas (ICCAT) confirmed that the North Atlantic stock was overfished and undergoing overfishing (International Commission for the Conservation of Atlantic Tunas [ICCAT], 2017, 2019). In 2018, the Shortfin mako was listed as endangered globally on the International Union for Conservation of Nature (IUCN) Red List due to their declining populations (Rigby et al., 2018).

Management of mako sharks is hindered by sparse biological information, including data on movements and habitat ecology (Sippel et al., 2015; Braccini et al., 2016). Until recently, such data for the western North Atlantic (WNA) had been primarily informed by fisheries landings and conventional tag-recapture studies (Casey and Kohler, 1992; Kohler et al., 2002; International Commission for the Conservation of Atlantic Tunas [ICCAT], 2017). While providing valuable information, these fisheriesdependent studies have limitations including low recovery rates, sampling efforts biased by the spatiotemporal distribution of fishing effort, and lack of movement information between capture and recapture events (Vaudo et al., 2017). Casey and Kohler (1992) hypothesized that mako shark movements were largely influenced by sea surface temperature which explained why they moved upward along the northeast coast of the United States and Canadian Grand Banks in the summer and early fall months before moving to the Sargasso Sea for the winter where more favorable thermal conditions were present. Vaudo et al. (2017) found that while mako sharks traveled through the Sargasso Sea, they did not reside there for any length of time. Additionally, their thermal range has been reported to vary more widely than previously thought with individuals inhabiting temperatures ranging from 5.2 to $31.7^{\circ} \mathrm{C}$, but mainly frequenting temperatures between 22 and $27^{\circ} \mathrm{C}$ (Vaudo et al., 2016).

More recently, satellite tracking of mako sharks in the WNA has begun to provide fisheries-independent observations, but these studies have been limited to short tracking periods or smaller size classes (Vaudo et al., 2017; Santos et al., 2018). Additionally, these studies have not included mako sharks that frequent the United States Gulf of Mexico (GOM), yet they do occur in the region (Baughman and Springer, 1950; Ajemian et al., 2016). Stock structure is largely unknown in the GOM and the lack of locations detected in this region in previous studies suggest possible metapopulation structure. Thus, the goal of this study was to provide new information on the movement ecology of shortfin mako sharks in the northwest Atlantic Ocean from animals tagged in the Gulf of Mexico. The specific objectives were to (1) identify mako shark seasonal movement and habitat use patterns and (2) estimate residency in the GOM.

\section{MATERIALS AND METHODS}

\section{Study Site and Tagging Procedure}

Shark handling and tagging was conducted in accordance with approved guidelines of Texas A\&M University-Corpus Christi (Institutional Animal Care and Use Committee-Animal Use Protocol \#08-18). Mako sharks were captured via hook and line $\geq 40$ nautical miles out of Port Aransas, Texas, or from shore along the Padre Island National Seashore. In these rare events, sharks were landed in the surf with their gills remaining submerged in water. Sharks captured offshore were either secured alongside the vessel or brought onboard via a cradle with a saltwater hose placed in the mouth to irrigate the gills. All sharks were tagged at their capture location. During the tagging procedure, individuals were sexed, measured [fork length (FL); cm], and externally tagged. Each individual was tagged with a smart position or temperature tag (SPOT5 or SPOT6; Wildlife Computers, Redmond, WA, United States) for satellite tracking and a conventional dart tag $\left(\right.$ Floy ${ }^{\odot}$, Seattle, WA, United States), which included a phone number, email address, unique identification number, and "REWARD" for reporting recaptures. For SPOT tag attachment, four small holes were drilled into the distal portion of the leading edge of the dorsal fin, and stainless-steel hardware was used to secure the tag. Prior to deployment, SPOT tags were coated in antifouling paint to prevent excessive biofouling that can inhibit communication with satellites. SPOT tags were programmed with a maximum of 70 transmissions per day and had an estimated battery life of $2+$ years. The Argos system assigned locations to one of seven accuracy classes, each with an associated error estimate. In decreasing order, the accuracy location classes (with estimated error) were: $3(<250 \mathrm{~m}), 2$ (250-500 m), 1 (500-1500 m), $0(>1500 \mathrm{~m})$, with unbounded accuracy for location classes $\mathrm{A}$, and $\mathrm{B}$. Class $\mathrm{Z}$ locations were considered 
poor location estimates (ARGOS, 2016) and, therefore, were omitted from further analyses. All other location classes were included in analyses.

\section{Data Analysis}

To provide new information on the seasonal movement ecology of mako sharks, statistical analyses were completed in $R$ version 3.5.2 (R Core Team, 2014). Mako shark tracks derived from tag location estimates were first filtered using a speed filter to remove travel speeds $>4.5 \mathrm{~m} / \mathrm{s}$ (Vaudo et al., 2017). Additionally, the first 11-days of the tracks were omitted to allow for dispersal from the tagging location and potential delayed mortality (Vaudo et al., 2017). Seasons were defined as follows: winter: DecemberFebruary, spring: March-May, summer: June-August, and fall: September-November.

A first-difference correlated random walk switching (DCRWS) model from the bsam package was used to characterize movement behaviors of individual sharks with at least 50 location estimates. This model allows for estimation of discrete behavioral modes at regular intervals during irregular time-series data, like satellite telemetry data (Jonsen et al., 2007). The resulting continuous random walk index estimates, which ranged from 1 (transiting behavior) to 2 (area-restricted behavior), were used to classify discrete behavioral modes with values $>1.75$ classified as area-restricted behavior and values $<1.25$ classified as transiting behavior (Jonsen et al., 2007). Values between 1.25 and 1.75 were considered unclassified behavior. Duration of transiting behavior was then calculated, and the start and end dates for each excursion were estimated.

To account for autocorrelation and irregularity of positions from SPOT-derived data, the estimated positions from the DCRWS (Jonsen et al., 2005) were used in further analyses. Seasonal kernel utilization distributions (KUD) were calculated using the adehabitatHR package with "href" as the smoothing parameter (h) (Calenge, 2015). Home range was calculated at 95\% KUD and core area was calculated at 50\% KUD (Simpfendorfer et al., 2012). Distance from each estimated position from the tagging location was calculated for each shark, and subsequently, plotted against days at liberty to visualize any patterns by size or sex (Lea et al., 2015).
Ambient depth, or the depth of ocean floor over which the shark was positioned, was extracted for analysis using the marmap package (Pante and Simon-Bouhet, 2013) because tags were not equipped with depth sensors. Sea surface temperatures were obtained from the JPL OurOcean Project (2010) using the Marine Geospatial Ecology Toolbox in ArcMap (version 10.6, ESRI, Redlands, CA, United States). Differences in seasonal ambient depth, distance from tagging location, and sea surface temperature were evaluated using a 2-way analysis of variance (ANOVA) with season as a fixed factor and individual as the random factor. If differences were detected, then Welch's $t$-test was used to parse out those differences. All tests were assumed significant at an $\alpha=0.05$ significance level.

\section{RESULTS}

From 2016 to 2020 , nine shortfin mako sharks were tagged with SPOT tags off the coast of Texas (5 M, 4 F; Table 1). Eight of the mako sharks were tagged $>40$ nautical miles offshore from Port Aransas, and one was tagged from shore along the Padre Island National Seashore, Texas. The five males (167$218 \mathrm{~cm} \mathrm{FL}$ ) were mature or nearing maturity, and all four females $(282-361 \mathrm{~cm}$ FL) were classified as mature based on published 50\% size-at-maturity data (males: $182 \mathrm{~cm}$, females: $280 \mathrm{~cm}$; Natanson et al., 2020). Two females had recent (i.e., fresh with no healing or scarring) bite marks anterior to the dorsal fin at capture which could suggest mating or fighting behaviors were occurring (Figure 1). One female was recaptured $3 \mathrm{~h}$ after being released post-tagging in the same location; this individual was subsequently re-released. Tracking duration varied widely from 10 to 887 days ( $m e a n=359$ days; median $=239$ days), with four mako sharks tracked for $>100$ days. At the conclusion of this study (April 2020), one male mako shark (Shark 5) was reporting.

To allow for dispersion from the tagging site, the first 11days of the tracks were omitted from movement analyses (Vaudo et al., 2017), which excluded the only female tagged from shore (Shark 2). Seasonal population level KUD analysis demonstrated year-round space use in the GOM, but a second area of use

TABLE 1 | Tagging information for shortfin makos tagged in the northwestern Gulf of Mexico, including size at tagging, tracking duration, days with usable detections, and status of SPOT tag at the conclusion of the study.

\begin{tabular}{|c|c|c|c|c|c|c|}
\hline Shark & Sex & Fork Length (cm) & Deployment Date & Days at Liberty & Days with Usable Positions & Still Reporting \\
\hline 1 & M & 168 & 25-February-2016 & 62 & 45 & No \\
\hline $2^{*}$ & $\mathrm{~F}$ & 290 & 26-March-2016 & 10 & 10 & No \\
\hline 3 & M & 210 & 8-April-2016 & 707 & 409 & No \\
\hline 4 & $\mathrm{~F}$ & 353 & 21-March-2017 & 887 & 482 & No \\
\hline 5 & M & 196 & 13-March-2018 & 697 & 536 & Yes \\
\hline 6 & M & 218 & 18-March-2018 & 70 & 60 & No \\
\hline 7 & $\mathrm{~F}$ & 361 & 19-March-2018 & 25 & 24 & No \\
\hline 8 & $\mathrm{~F}$ & 282 & 19-March-2018 & 16 & 11 & No \\
\hline 9 & M & 167 & 28-February-2019 & 408 & 235 & No \\
\hline
\end{tabular}

*denotes the female that was recaptured, but due to a short track duration was excluded from further analysis. 

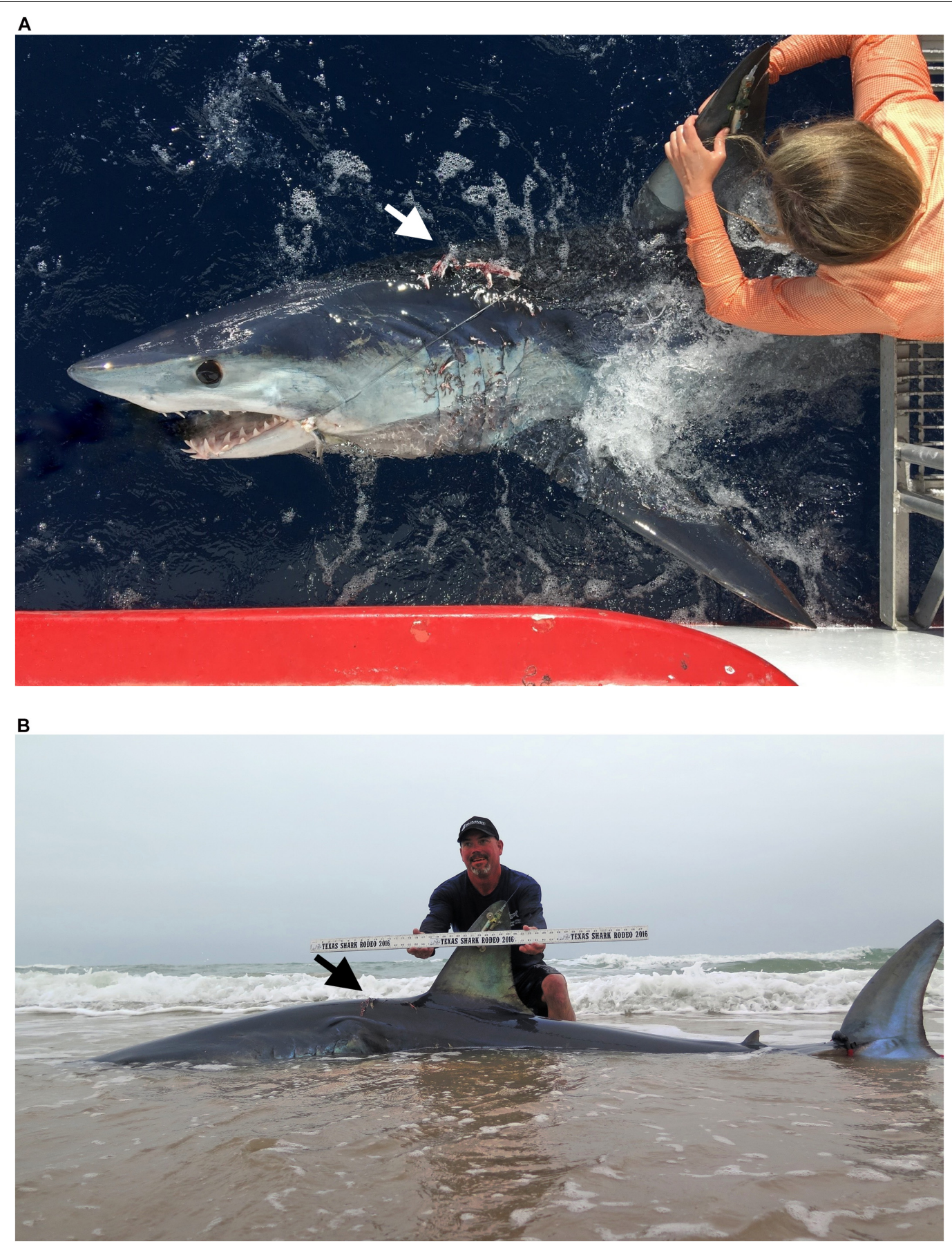

FIGURE 1 | Bite marks (arrows) observed on female shortfin makos, suggesting potential mating or fighting behaviors in the Gulf of Mexico. (A) Shark 6 was tagged offshore in 2017. (B) Shark 1 was tagged in 2016 from Padre Island National Seashore and was recaptured and released $3 \mathrm{~h}$ later in the same location.

appeared in the summer and fall months in the WNA (Figure 2). Two mature males that were tracked for multiple years exited the GOM during the summer months and returned to the northwestern GOM in the winter months (Figure 3). Shark 3 traveled to the Caribbean Sea in two consecutive summers and returned to the Texas coast in late fall each year. Shark 5 traveled through the Straits of Florida and up the Atlantic coast to the northeast United States in two consecutive summers, returning the first year during winter. As of the conclusion of data collection for this study (April 2020), Shark 5 was still reporting off the Texas coast in the GOM, consistent with the previous year's movement patterns.

For both of these male sharks (Sharks 3 and 5), these long excursions were characterized by directionally persistent 

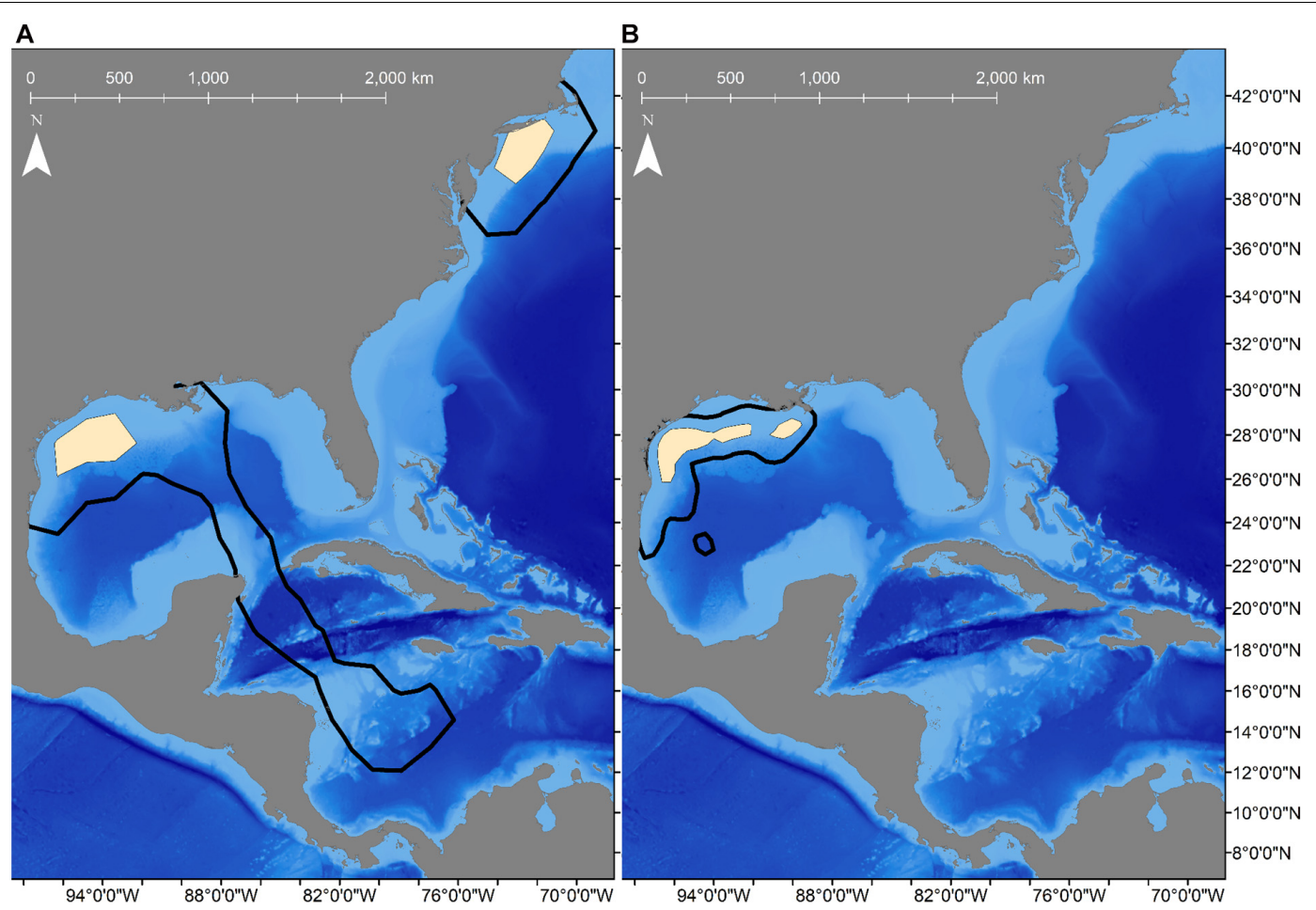

C

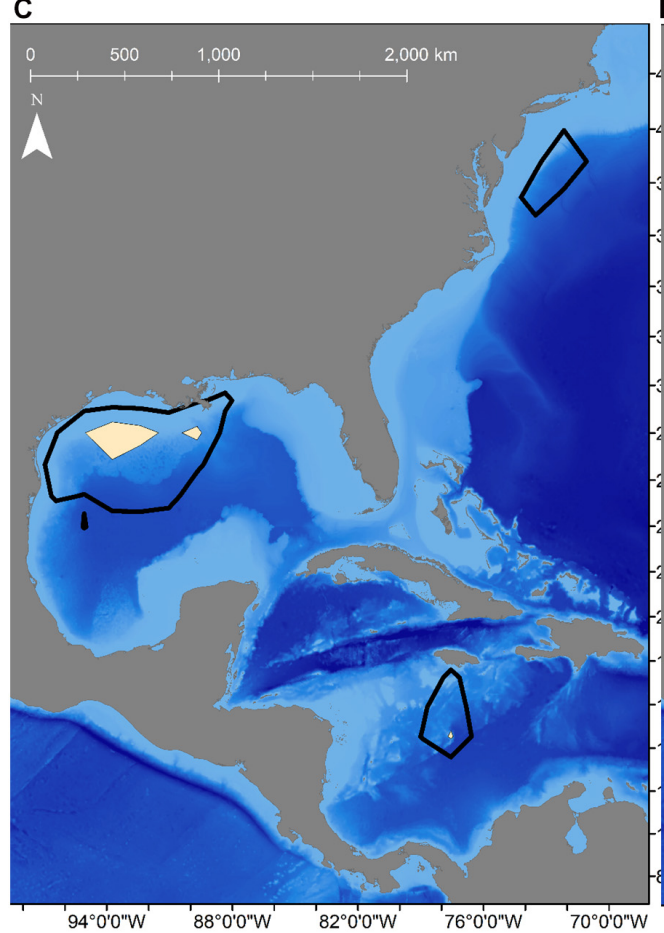

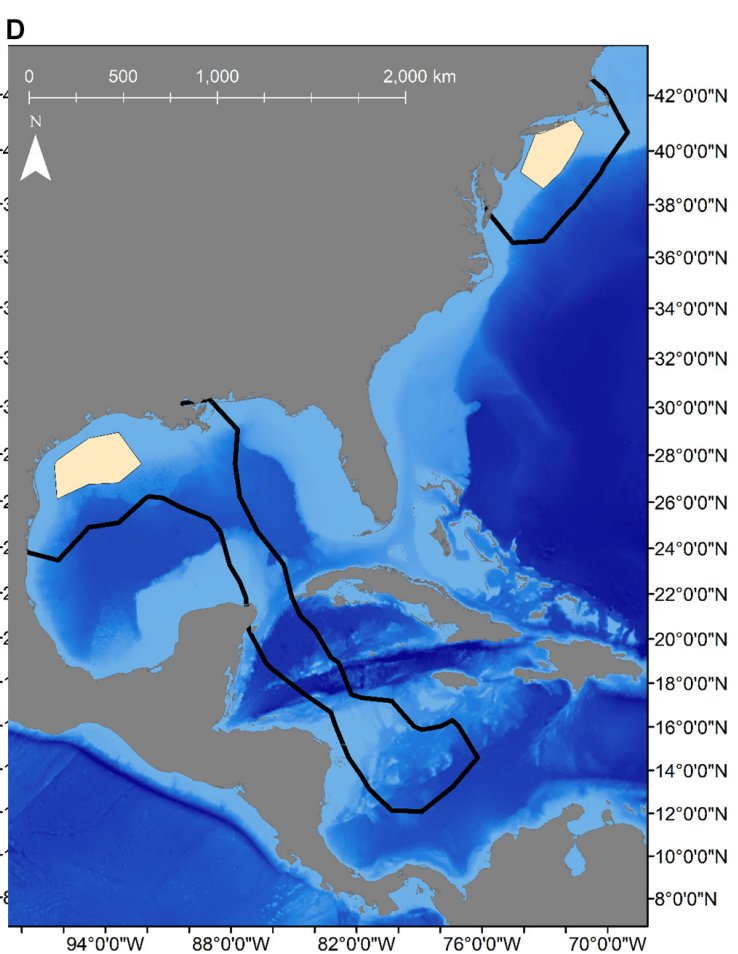

FIGURE 2 | Seasonal population-level Kernel Utilization Distributions (KUD) calculated from satellite-tracked shortfin makos tagged off the Texas coast showing space use changed with the seasons. Black lines represent home range (95\% KUD) and tan shaded areas are core area (50\% KUD). (A) KUDs calculated for winter ( $n=5$ sharks) shows core areas in the northwestern Gulf of Mexico (GOM), but areas off the eastern United States coast was used as well. (B) KUDs for spring ( $n=9$ sharks) shows that makos remained in the GOM extensively along the continental shelf and slope. (C) KUDs calculated for summer ( $n=5$ sharks) showed more area off the shelf was used in the GOM as well as in the Caribbean Sea and off the northeast coast of the United States. (D) KUDs for fall ( $n=4$ sharks) showed two core areas were used in the North Atlantic, including in the northwestern GOM and off the northeastern United States coast. 


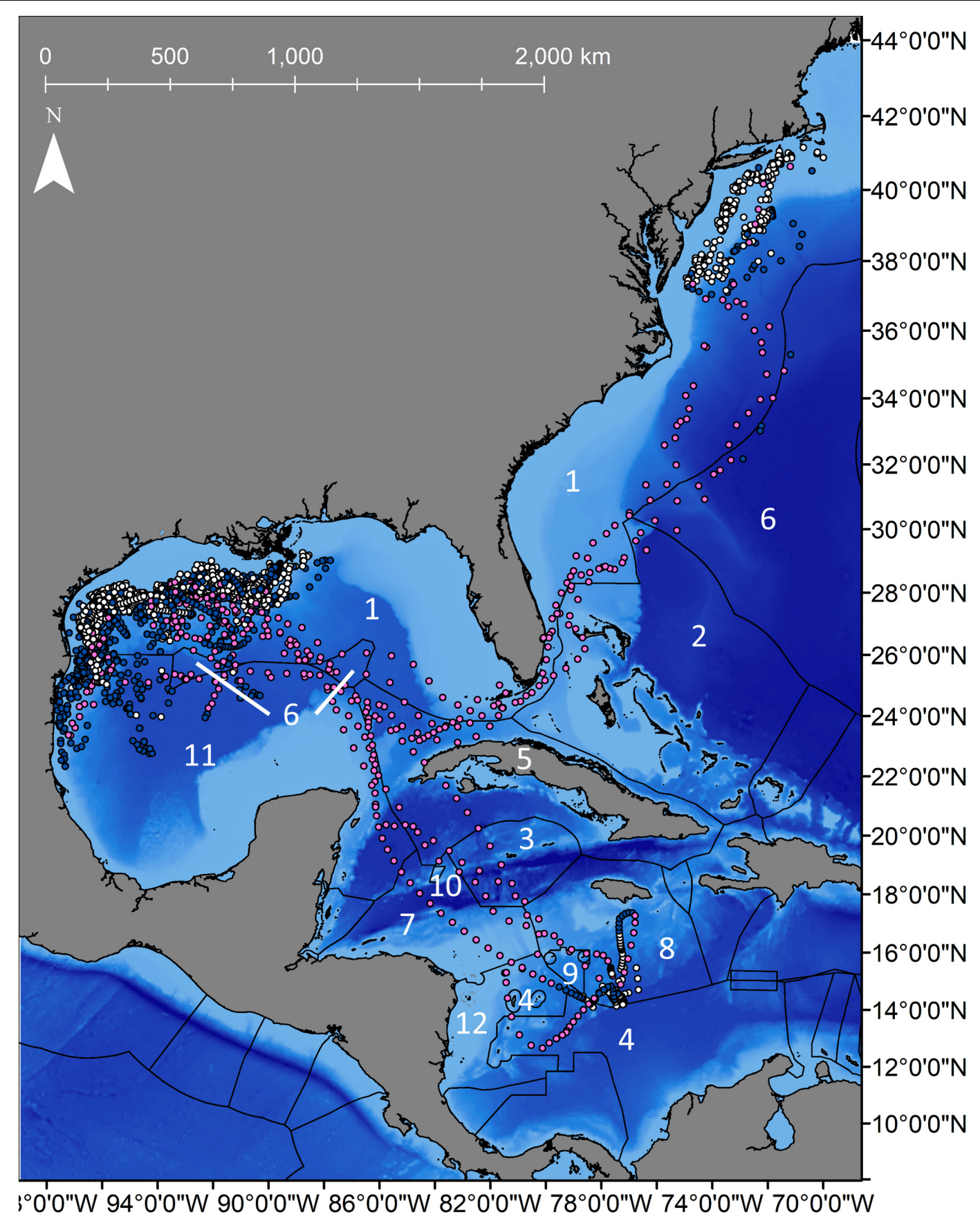

FIGURE 3 | Daily locations for 8 shortfin makos tagged in the northwestern Gulf of Mexico with Exclusive Economic Zones (EEZ) for each country. Navy dots represent resident behavior based on the first-difference correlated random walk switching model, while pink dots represent transiting behavior. Gray dots represent unclassified behavior. EEZs that sharks transited through are represented by numbers that correspond countries listed in Table 2.

migration followed by a long seasonal residency period before returning to the GOM. Based on the DCWRS model behavioral mode classifications, excursion durations varied with Shark 3 (227 days) spending more time in the western GOM than Shark 5 (100 days), which returned to the northwestern GOM about 3 months after Shark 3; however, transit time to (Shark 3: 32-40 days; Shark 5: 34-44 days) and from (Shark 3:
40-58 days; Shark 5: 60-70 days) their respective destinations was comparable (Figures 4, 5). Both Shark 3 and Shark 5 each traveled about $2500 \mathrm{~km}$ to their respective destinations (Figure 6). Conversely, Shark 9, an immature male, did not exit the western GOM, but rather moved into the southwestern GOM near the Mexican shoreline before moving into deeper water and returning northward toward the continental shelf off the Texas 


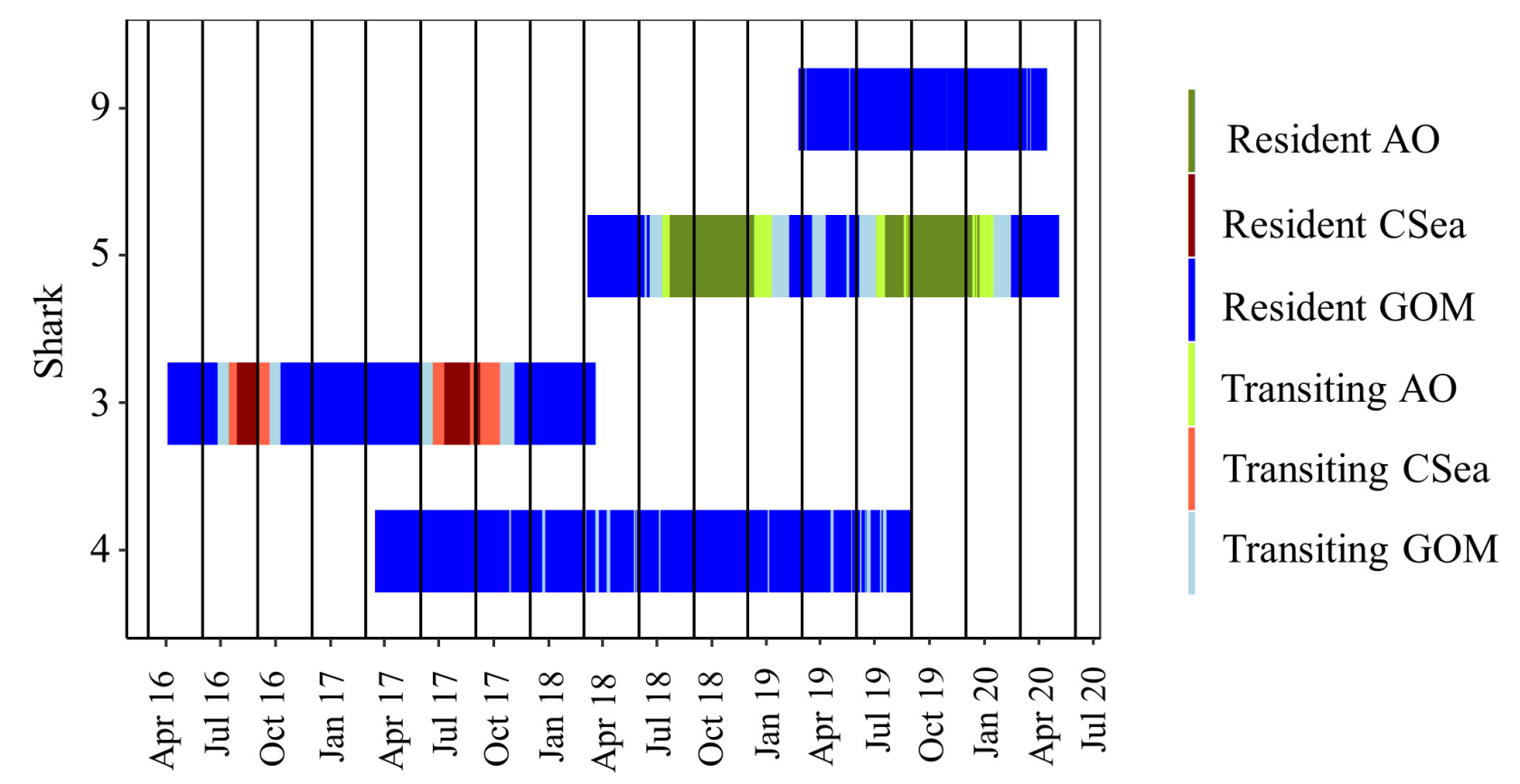

FIGURE 4 | Movement behavior of shortfin makos tracked > 100 days over the study period. Sharks demonstrated transiting behavior (light colors) and resident behavior (dark colors) based on the first-difference correlated random walk switching model. Shades of blue represents periods within the Gulf of Mexico (GOM), green represents periods within the Atlantic Ocean (AO), and red represents periods within the Caribbean Sea (CSea). Sharks 5 and 3 were mature males tracked through multiple migrations. Shark 4 was the only female tracked $>100$ days. Shark 9 was the only immature male tracked $>100$ days.

coast. However, these movements were classified as unknown behavioral modes by the DCWRS model. Shark 4, a female, similarly remained in the GOM, but after 827 days of transiting between the Flower Garden Banks National Marine Sanctuary (FGBNMS) and north central GOM near the Mississippi River Delta, she moved off the continental shelf into deeper water for the first-time (early summer) where she remained for 30 days before returning to the continental shelf near the FGBNMS. These movements were classified as both transiting and resident behavioral modes by the model (Figure 5).

Mako sharks traversed a geographical area of $12.8^{\circ}-41.2^{\circ}$ $\mathrm{N}$ latitude and $69.8^{\circ}-97.7^{\circ} \mathrm{W}$ longitude, which included the Atlantic Ocean, GOM, Caribbean Sea, and the management jurisdictions for at least 12 nations and international waters (Table 2). Tagged mako sharks frequented a wide range of sea surface temperatures ranging from $10.0^{\circ}-31.0^{\circ} \mathrm{C}$ (Figure 7), although no significant differences were detected among seasons $\left(F_{1,2969}=0.65, \mathrm{p}=0.58\right.$; Table 3$)$. Despite the long-distance excursions by two males, mean monthly distance traveled was not significantly different by sex $\left[F_{1,3}=0.89, p=0.99\right.$; mean \pm standard deviation (SD): male: $1,958 \pm 1,035 \mathrm{~km} /$ month, females: $1,836 \pm 875 \mathrm{~km} / \mathrm{month}]$. For ambient depth, there were no significant differences among seasons $\left(F_{3,2969}=0.23, p=0.87\right)$, although males were tracked over deeper depths than females in all seasons except spring (Table 3 and Figure 8). These tracks over deeper ambient depths aligned with observed transiting behaviors (Figure 5).

\section{DISCUSSION}

During the study period, mako sharks demonstrated varied movement patterns which included both coastal and oceanic habitats. Most mako sharks tagged in this study were mature based on size-at-age information with females in this study representing some of the largest females reported in satellite telemetry studies to date (e.g., Loefer et al., 2005; Abascal et al., 2011; Musyl et al., 2011; Rogers et al., 2015; Campana et al., 2016; Byrne et al., 2017; Vaudo et al., 2017; Francis et al., 2019; Nasby-Lucas et al., 2019). Although sample size was limited, the multi-year movement patterns observed for males differed from the lone female tracked multiple years. The female demonstrated high fidelity to the GOM along the continental shelf for most of the year, while mature males made extensive large-scale migrations that crossed multiple management jurisdictions, demonstrating the need for cooperative international management to conserve and rebuild the declining WNA stock.

Multi-year tracks from the three mature individuals showed fidelity to the GOM varying by season and sex. While the mature female remained in the northwestern GOM year-round, the mature males demonstrated seasonal excursions with individuals exiting the GOM beginning in the late summer-early fall and returning in late fall-early winter each year. While the timing of these directed migrations showed a pattern, the destination of these excursions and residency time at each destination varied individually. For all mako sharks tracked during the study, home 

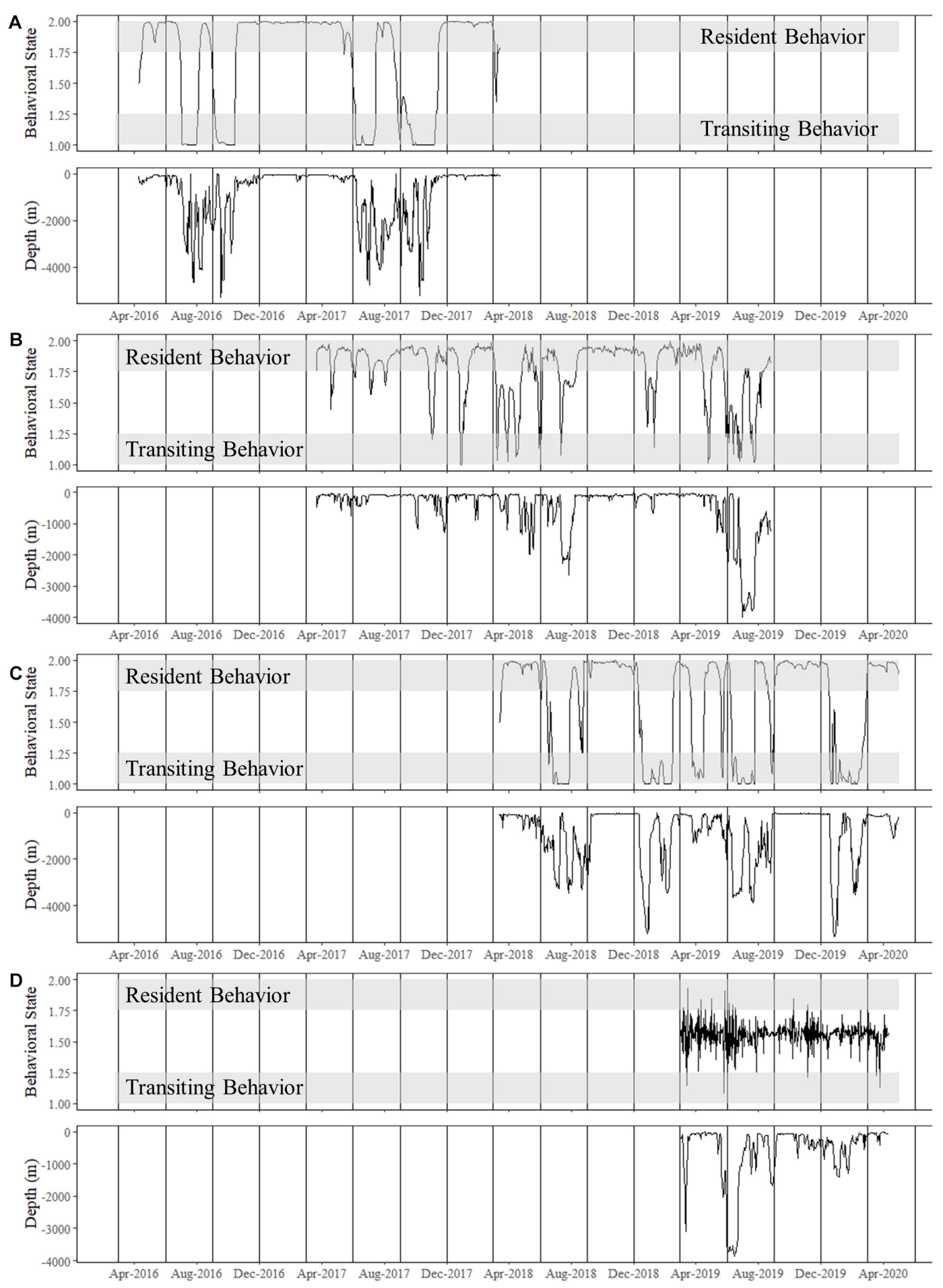

FIGURE 5 | Time series of estimated behavioral state for shortfin makos tracked for multiple years compared to ambient depth use (m), or depth of ocean floor over which the shark was positioned. Note that deeper ambient depths were observed when sharks were transiting. Vertical lines represent the start of each season: summer (June-August), fall (September-November), winter (December-February), and spring (March-May). (A) Shark 4, a mature female, spent all her time in the Gulf of Mexico with transiting behavior matching movements to and from the Mississippi River Delta and the Flower Gardens National Marine Sanctuary. Until June-July 2019, Shark 4 remained predominantly on the continental shelf or slope. (B) Shark 3, a mature male, made two consecutive excursions to the Caribbean Sea over largely open ocean and deeper water. (C) Shark 5, a mature male, made an excursion to the northeast United States during the first year of tracking and was on his second excursion at the conclusion of this study. This male traveled over deeper water exiting the Gulf of Mexico before predominately following the continental shelf up the eastern coast. (D) Shark 9 was an immature male that was only tracked within the western Gulf of Mexico. 


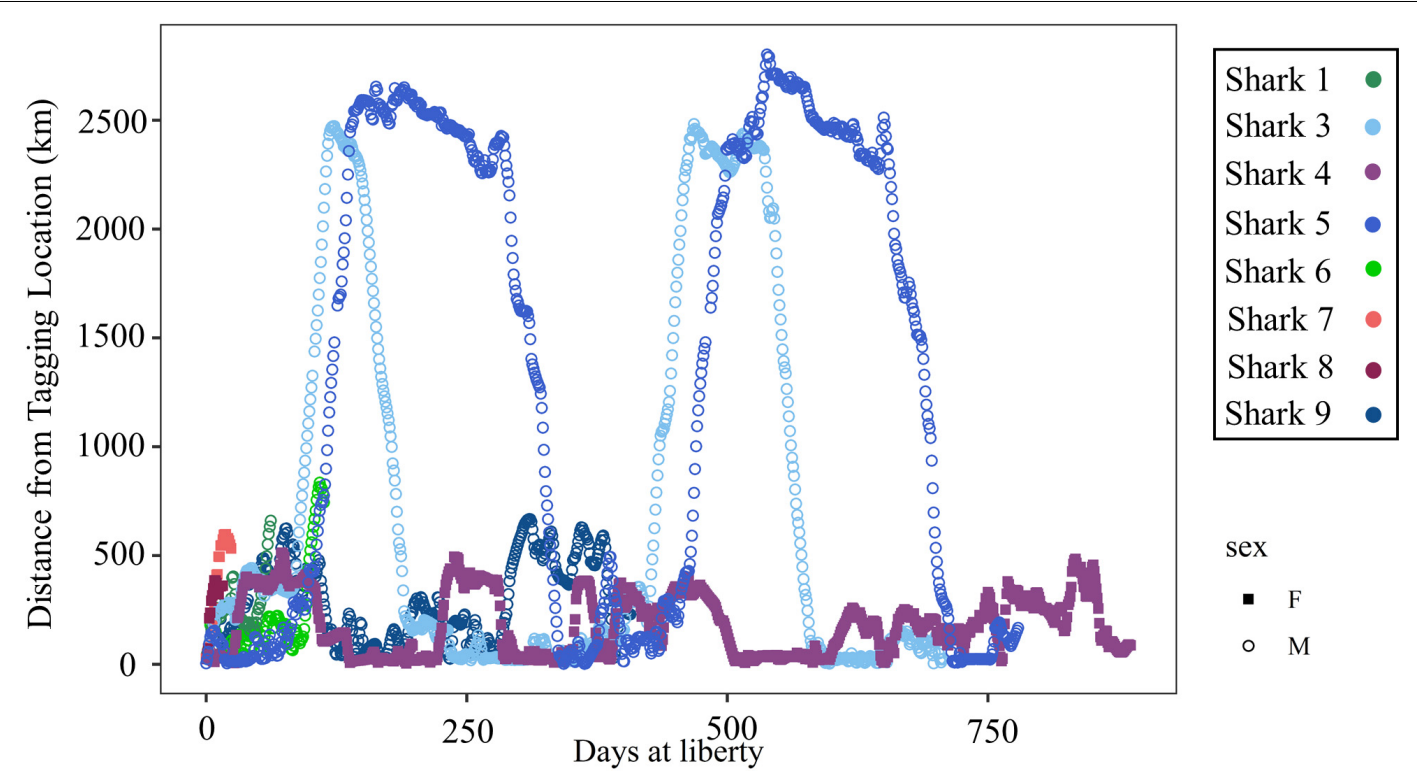

FIGURE 6 | Distance $(\mathrm{km})$ of daily locations from the tagging location plotted by days at liberty since the tagging date for 8 shortfin makos tagged in the northwestern Gulf of Mexico. Females are represented by closed squares and males by open circles. Individual sharks are represented by unique colors.

range during the spring was limited to the GOM when both sexes were present in the northwestern GOM. During the other seasons, home range included additional areas outside the GOM. Home range calculated for mature mako sharks overlapped with the home range reported for juvenile mako sharks for both the GOM and WNA in each season, except for spring, when home range overlapped only in the GOM. This overlap in home range predominately occurred during transiting behavior by mature individuals in this study. Core areas (e.g., more resident behavior) of individuals in this study overlapped previously reported core areas of juveniles only during summer and fall months in the WNA but never in the GOM (see Vaudo et al., 2017 for comparison).

Temperature has been suggested to be a physiological constraint on movements of juvenile mako sharks within the GOM (Vaudo et al., 2016, 2017). However, no differences in sea surface temperatures were detected in this study, despite movements to more southern and northern areas. This finding may be related to the size of mako sharks tagged in this study (mostly mature individuals) versus previous studies that have tagged mostly juveniles. Vaudo et al. (2016) reported that their juvenile mako sharks tagged off the WNA showed southernly directional movements in November and December as sea surface temperatures dropped. These directional movements have also been reported in other studies in the Pacific Ocean (Abascal et al., 2011; Block et al., 2011). Juveniles tagged off the Yucatan Peninsula showed no clear directional patterns (Vaudo et al., 2016). This lack of pattern was attributed to the steady sea surface temperatures reported for this area and the GOM (Longhurst, 2007). Thus, while sharks may be selectively remaining within a preferred temperature, the lack of difference in frequented sea surface temperatures and the directional movements by mature males in this study suggest the minimal overlap in home range may be influenced by other reasons, such as size segregation (Sippel et al., 2015; Nasby-Lucas et al., 2019).

Mako sharks have been shown to use a variety of habitats during their long-distance excursions, including open-ocean and more shallow waters along the continental shelf. This pattern was demonstrated in the current study with individuals occurring over deeper depths (i.e., open ocean) during transiting periods and in shallower ambient depths (i.e., continental shelf) during periods of residency, a phenomenon observed for many marine megafauna (Sequeira et al., 2018). Although rare, recreational anglers have reported catching large, mature mako sharks from shore (Gibson et al., 2019, Stunz unpublished data). This coastal, nearshore habitat use, which has also been reported in previous studies (Francis et al., 2019), exposes this generally pelagic species to shore-based fisheries. While most individuals in this study were mature, previous studies on juveniles have also reported similar habitat use patterns between open-ocean and continental shelf use (Rogers et al., 2015; Vaudo et al., 2017; Byrne et al., 2019). Juveniles tagged off the Yucatan Peninsula demonstrated high residency to the eastern edge of the Campeche Bank (Vaudo et al., 2017; Byrne et al., 2019), and juveniles tagged off the coast of Australia exhibited high site fidelity to the mid-outer continental shelf near the Great Australian Bight (Rogers et al., 2015). This shallower, continental shelf habitat is likely attractive due to the abundance and variety of prey available compared to open-ocean habitats (Byrne et al., 2019). Nevertheless, mako sharks often occur as bycatch in pelagic longline fisheries in open-ocean waters (Campana et al., 2005). Extensive seasonal offshore movements and pelagic bycatch occurrences suggests that mako movements may be linked to foraging behavior following a selected food source (Nasby-Lucas et al., 2019). Diet 
TABLE 2 | Regulations for each of the management jurisdictions that tagged mako sharks passed through during their excursions from the tagging region in the northwestern GOM.

\begin{tabular}{ll}
\hline EEZ & Regulations \\
\hline United States (1) & Amendment 11: \\
Minimum size: 71 in FL for males; 83 in FL for females \\
Non-off, corrodible circle hooks must be used when targeting sharks in the \\
recreational fishery, except when using artificial lures or flies. \\
(1) For all commercial vessels: \\
(a) Mako sharks may be retained if reporting requirements (e.g., observer or \\
electronic monitoring system which can identify if the shark is alive or not) are met. \\
(b) Mako shark is dead at haul back \\
(c) Data on the number of individuals hooked, body length, sex, condition, maturity \\
(whether the individual is pregnant and its litter size) and weight of products for each \\
shortfin mako caught as well as fishing effort \\
(d) When mako sharks are not retained, the number of dead discards and live \\
releases shall be recorded by the observer or estimated from the records of the \\
electronic monitoring system \\
Shark sanctuary
\end{tabular}

Cayman Islands (3)

Colombia (4)

Cuba (5)

High Seas (6)

Honduras (7)
National Conservation Law (2013):

No take

Sharks must be landed with fins naturally attached to their bodies

All sharks caught be landed whole with fins attached

No take

Jamaica (8)

Joint:

Colombia/Jamaica (9)

Joint:

No take

Honduras/Cayman

Islands (10)

Mexico (11)
NORMA Oficial Mexicana NOM-029-PESC-2006 and NORMA Oficial Mexicana NOM-023-SAG/PESC-2014:

Minimum size: 71 in FL for males; 83 in FL for females

(1) For commercial vessels whose length is greater than $12 \mathrm{~m}$ :

(a) Mako sharks may be retained if reporting requirements (e.g., observer or electronic monitoring system which can identify if the shark is alive or not) are met. (b) Mako shark is dead at haul back

(c) Data on the number of individuals hooked, body length, sex, condition, maturity (whether the individual is pregnant and its litter size) and weight of products for each shortfin mako caught as well as fishing effort

(d) When mako sharks are not retained, the number of dead discards and live releases shall be recorded by the observer or estimated from the records of the electronic monitoring system

(2) For vessels whose length is equal or smaller than $12 \mathrm{~m}$ :

(a) Mako sharks may be retained if dead when brought along side for taking on board the vessel

No fin exports without proof that the meat was sold

\section{References}

International Commission for the Conservation of Atlantic Tunas [ICCAT], 2020

https://www.dcnanature.org/wp-content/uploads/ 2015/06/Pew-Protecting-Sharks-Caribbean-

FactSheet.pdf

http://doe.ky/marine/sharks/

https://awionline.org/content/international-sharkfinning-bans-and-policies

http://blogs.edf.org/edfish/2015/07/02/cubasplan-for-shark-conservation/

https://www.dcnanature.org/wp-content/uploads/ 2015/06/Pew-Protecting-Sharks-CaribbeanFactSheet.pdf

http://doe.ky/marine/sharks/

https://www.dcnanature.org/wp-content/uploads/ 2015/06/Pew-Protecting-Sharks-Caribbean-

FactSheet.pdf

International Commission for the Conservation of Atlantic Tunas [ICCAT], 2020 https://awionline.org/content/international-sharkfinning-bans-and-policies

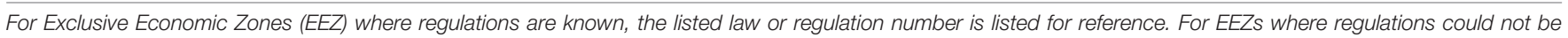
found, it is assumed no regulations exists for mako sharks and the regulations were left blank. Numbers in parentheses represent EEZs in Figure 3.

and stable isotope studies suggested that mako sharks prey on a variety of nearshore and offshore fish species like bluefish (Pomatomus saltatrix), tuna (Thunnus spp.), and swordfish, as well as cephalopods and other sharks (e.g., blue shark, Prionace glauca; Stillwell and Kohler, 1982; Compagno, 2001; Estrada et al., 2003; Campana et al., 2005; Wood et al., 2009). While exact drivers for long-distance movements are still unclear, similar offshore patterns for other apex species, like white 

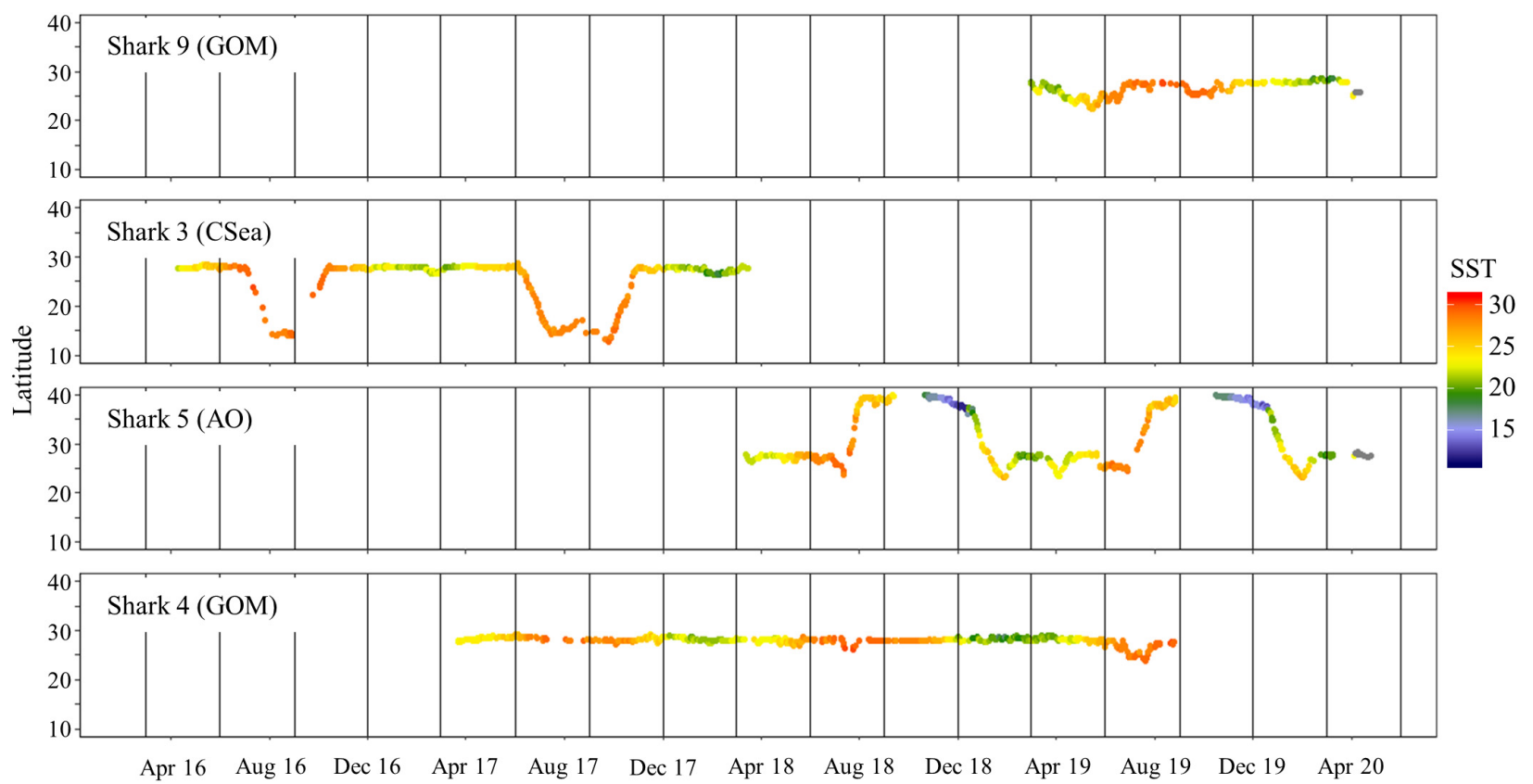

FIGURE 7 | Daily latitude estimates and associated sea surface temperature (from satellite remote-sensing data; ${ }^{\circ} \mathrm{C}$ ) for four shortfin makos tracked for $>1$ year in the western North Atlantic Ocean. Sharks 4 and 9 remained in the Gulf of Mexico while sharks 3 and 5 migrated out of the Gulf of Mexico. Destinations (GOM, Gulf of Mexico; AO, Atlantic Ocean; and CSea, Caribbean Sea) of mako sharks after migration are in parentheses. Vertical lines represent the start of each season: summer (June-August), fall (September-November), winter (December-February), and spring (March-May).

TABLE 3 | Mean sea surface temperature $\left({ }^{\circ} \mathrm{C}\right)$ and ambient depth $(\mathrm{m})$ with standard deviations for mako sharks tracked in this study.

\begin{tabular}{lcccc}
\hline \multicolumn{3}{c}{ SST } & & Depth \\
\hline Season & Male & Female & Male & Female \\
\hline Winter & $21.2 \pm 3.1$ & $20.9 \pm 1.4$ & $-668 \pm 1241$ & $-103 \pm 149$ \\
$(n=5)$ & $(19,24)$ & $(10,26)$ & $(-5336,-5)$ & $(-1009,-22)$ \\
Spring & $23.4 \pm 2.1$ & $23.8 \pm 1.9$ & $-405 \pm 448$ & $(-3819,-14)$ \\
$(n=9)$ & $(20,29)$ & $(20,29)$ & $-1827 \pm 1232$ & $-1026 \pm 1118$ \\
Summer & $28.0 \pm 1.4$ & $29.0 \pm 1$ & $(-4682,-31)$ & $(-3788,-57)$ \\
$(n=5)$ & $(25,31)$ & $(25,31)$ & $-307 \pm 1084$ & $-181 \pm 252$ \\
Fall & $21.4 \pm 5.5$ & $27.6 \pm 1.9$ & $(-4579,-1)$ & $(-1552,-65)$ \\
$(n=4)$ & $(12,31)$ & $(23,30)$ & & $(-3442,-12)$ \\
\hline
\end{tabular}

Minimum and maximum sea surface temperatures and ambient depths are represented in parenthesis below the means. Sample size of sharks tracked in each season is in parentheses below the season. Males traversed over waters with deeper depths during the winter, summer, and fall seasons.

sharks (Carcharodon carcharias), blue sharks, and salmon sharks (Lamna ditropis; Holts et al., 1998) have been reported, as well as for their prey items (Block et al., 2005; Hoolihan et al., 2014; Rooker et al., 2019). However, that does not explain the sexspecific differences in movement patterns for mature sharks tagged in this study. Although inferences are limited based on the low sample size in this study, we hypothesize that these differences may be driven by reproduction.

The locations of mating grounds are not yet known for mako sharks; however, two of the four females in this study had fresh bite marks present at time of tagging (late March), while mature males were also present in the tagging region at this time with no bite marks observed. Although these bites could be the result of fighting behavior, the bites may also be the result of mating behaviors, suggesting the GOM may serve as a mating ground. Mating is generally thought to occur during late fall/winter in both hemispheres (Mollet et al., 2000). Male mako sharks in this study were transiting during summer (leaving the GOM) and early winter (returning to the GOM) months, suggesting that mako sharks in the GOM might be mating slightly later in the year than in other regions or that some males may leave the GOM to reproduce elsewhere. This supports the possibility of multiple reproductive stocks as suggested by Schrey and Heist (2003) who proposed that seasonality of mating may be shifted by male sharks to accommodate the availability of fertile females. Sexbiased dispersal has been previously reported in mako sharks in the Pacific Ocean (Mucientes et al., 2009) and Indian Ocean 


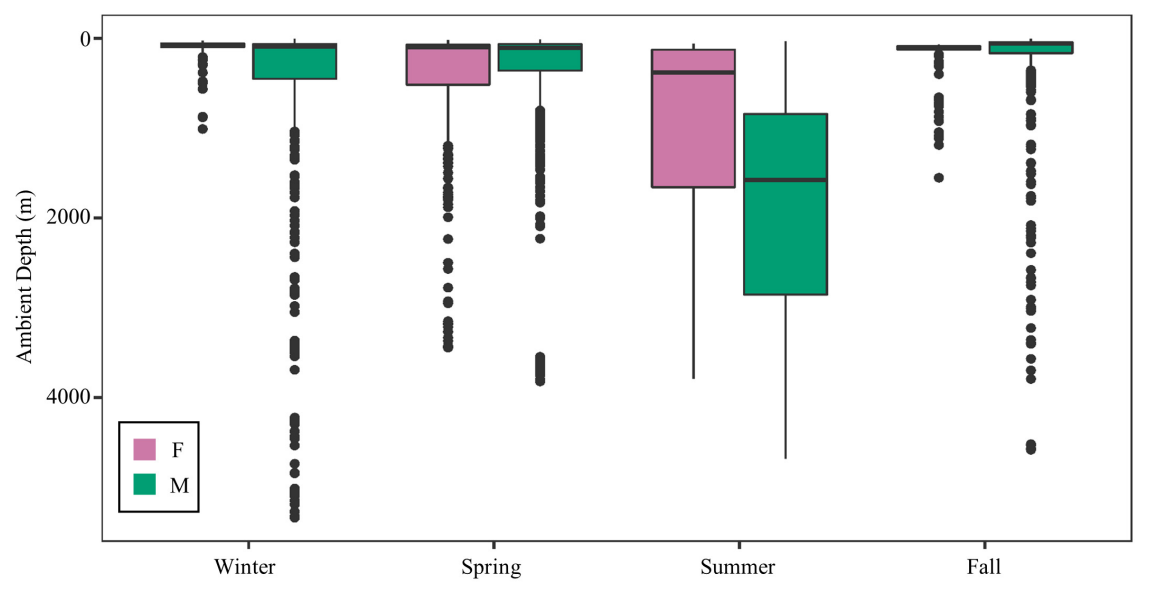

FIGURE 8 | Seasonal ambient water depth $(m)$ by sex. Males frequented a wider range of ambient depths except during the spring, which was the only season when both sexes were located in the Gulf of Mexico during the entire season.

(Corrigan et al., 2018), with males making large movements while females were philopatric (Mollet et al., 2000; Schrey and Heist, 2003). Differences in movement patterns may be a result of sexual segregation (Mucientes et al., 2009). Females may also be avoiding highly aggressive mating behaviors which often result in serious bite wounds that could result in decreased fitness of females (Stevens, 1974; Magurran and Seghers, 1994). Sexual segregation has been reported in the White Shark, a species also in the family Lamnidae, that has seasonal site fidelity to potential breeding and pupping grounds (Bonfil et al., 2005; Jorgensen et al., 2010; Anderson et al., 2011; Domeier and Nasby-Lucas, 2013).

Although little is known about exact pupping grounds, Casey and Kohler (1992) observed young-of-the-year offshore in the Gulf of Mexico and hypothesized that mako sharks in the WNA are born far offshore, likely to protect the pups from predation. One female mature mako in this study was tracked $>2.5$ years during which time she remained on the continental shelf and slope for $>2$ years until early summer when she moved further offshore for 30 days before returning to the continental shelf. Although pregnancy cannot be confirmed, this change in behavior is consistent with the hypothesis put forth by Casey and Kohler (1992). Additional tagging should bolster sample size and aid in the identification of any differences in habitat utilization while both sexes are present in the GOM.

Tagging studies including ours and others (e.g., Vaudo et al., 2017) suggest spatial substructure within the North Atlantic stock and warrant possible consideration of more regional management strategies as the failure to accurately identify and manage sub-stocks could result in overfishing and depletion of less productive sub-stocks (Ricker, 1981; Smith et al., 1991). While genetic analyses do not support the presence of genetically distinct stocks for mako sharks in the WNA, they do suggest multiple reproductive stocks may exist with considerable malemediated gene flow (Heist et al., 1996; Schrey and Heist, 2003). These genetic analyses should be interpreted with caution when proposing a single stock management approach, as a large number of migrants per-generation are required to replenish overfished stocks and can be difficult to demonstrate using genetic studies alone (Waples, 1998; Schrey and Heist, 2003). The movements we observed for mature mako sharks in this study generally support the possibility of distinct reproductive stocks proposed by Schrey and Heist (2003); however, the number of mako sharks tracked for more than one season was limited in this study, so there is a need for additional tagging studies of mature mako sharks to validate current knowledge of movement ecology and test the hypothesis of multiple reproductive stocks.

Management of highly migratory shark species, such as mako sharks, is complicated because they cross multiple management jurisdictions and long-term movement data remains limited. Mako sharks in this study passed through at least 12 management jurisdictions subjecting them to varying levels of fishing pressure and regulations (Table 2). This means that they may be protected or managed in some jurisdictions and not in others, highlighting the need for coordinated management. For example, Byrne et al. (2017) reported that 12 of 40 (30\%) satellite-tagged juvenile mako sharks tracked in the WNA were harvested by vessels from five countries, including the United States, Canada, Mexico, Spain, and Cuba. Just within the GOM, mako sharks were subject to regulations enforced by the United States and Mexico or lack thereof in Cuba and the High Seas. While the United States and Mexico are members of ICCAT, Cuba ceased participation in 1991 (Kraus et al., 2011). Further complicating management, even members of ICCAT do not agree on steps needed to protect the WNA mako shark population and provide spatial refuge from fishing effort, which is currently lacking even in the High Seas (Sims et al., 2018; Queiroz et al., 2019). Cooperative international management, though complicated and complex, is needed to reduce fishing mortality and rebuild the declining North Atlantic stock. Results from this study 
demonstrate that mako sharks in the GOM can undertake large-scale movements and may exhibit sex-specific movement patterns. The mature female tracked over multiple years showed high fidelity to the GOM, which may serve as potential mating and parturition grounds. Females in this study were some of the largest reported in satellite telemetry studies, providing data on a size class and breeding stock that has largely been unavailable until now. If mature female mako sharks show philopatry to relatively small areas within national EEZs that adopt and enforce current management recommendations, these regions may have a disproportionate impact on rebuilding and emphasize the need for national management. Correspondingly, large-scale movements across multiple jurisdictional boundaries observed for mature males in this study emphasize the need for international cooperative management to conserve this species. Recent tagging studies like ours and others suggest migratory variations and potential sex- and size-based segregation within the North Atlantic stock that may warrant consideration in future management strategies. Thus, while our study provides new information on the movement ecology for mako sharks in the WNA, especially for mature individuals that have been underrepresented in previous scientific efforts, additional tagging efforts focused on mature individuals are needed to identify mating and parturition grounds and better assess the patterns observed here. These studies will allow a robust evaluation of the possibility of multiple reproductive stocks, leading to more management confidence and aid rebuilding efforts.

\section{DATA AVAILABILITY STATEMENT}

The datasets presented in this study can be found in online repositories. The names of the repository/repositories and accession number(s) can be found below: Integrated Ocean Observing System: Animal Telemetry Network (https:// portal.atn.ioos.us/?ls=948413b4-471b-b5e6-6f19-c4b6d6fdfb06\# metadata/e3849570-c263-4e3b-8a51-31ff672a90b4/project).

\section{REFERENCES}

Abascal, F. J., Quintans, M., Ramos-Cartelle, A., and Mejuto, J. (2011). Movements and environmental preferences of the shortfin mako, Isurus oxyrinchus, in the southeastern Pacific Ocean. Mar Biol. 158, 1175-1184. doi: 10.1007/s00227011-1639-1

Ajemian, M. J., Jose, P. D., Froeschke, J. T., Wildhaber, M. L., and Stunz, G. W. (2016). Was everything bigger in Texas? Characterization and trends of a landbased recreational shark fishery. Mar. Coast. Fish. 8, 553-566. doi: 10.1080/ 19425120.2016.1227404

Anderson, S. D., Chapple, T. K., Jorgensen, S. J., Klimley, A. P., and Block, B. A. (2011). Long-term individual identification and site fidelity of white sharks, Carcharodon carcharias, of California. Mar. Biol. 158, 1233-1237. doi: 10.1007/ s00227-011-1643-5

ARGOS (2016). Argos User's Manual. Toulouse: CLS/Service Argos.

Baughman, J. L., and Springer, S. (1950). Biological and economic notes on the sharks of the Gulf of Mexico, with especial reference to those of Texas, and with a key for their identification. Am. Midl. Nat. 44, 96-152. doi: 10.2307/2421758

\section{ETHICS STATEMENT}

Written informed consent was obtained from the individual for the publication of any potentially identifiable images or data included in this article. The animal study was reviewed and approved by the Texas A\&M University-Corpus Christi's Institutional Animal Care and Use Committee.

\section{AUTHOR CONTRIBUTIONS}

KG conducted the research and wrote the manuscript. MS assisted in data analyses and writing the manuscript. TT conducted the research and assisted in writing the manuscript. GS acquired funding, conducted the research, and assisted in the data analyses and writing the manuscript. All authors gave authorization for submission.

\section{FUNDING}

Funding for the field studies and data analysis was provided in part by the Harte Research Institute for Gulf of Mexico Studies, the Texas State Aquarium, the John M. O'Quinn Foundation, and the Coastal Conservation Association - Texas.

\section{ACKNOWLEDGMENTS}

We would like to thank the staff and students of the Center for Sportfish Science and Conservation at the Harte Research Institute for Gulf of Mexico Studies for their assistance in the field, and Dr. Brandt Gibson for his help troubleshooting with R code, Eric Ozolins, Dwade Hickey, Ricky Torres, Captain Chad Banks, Captain "Jx" Yeaney, Captain Fred Mallett, and the crew of the Fisherman's Wharf for their help in the field. Considerable logistical support was provided by the Harte Research Institute and Texas A\&M University-Corpus Christi. We would also like to thank OCEARCH for their support and display of our tagged sharks on their Global Shark Tracker website.

Block, B. A., Jonsen, I. D., Jorgensen, S. J., Winship, A. J., Shaffer, S. A., Bograd, S. J., et al. (2011). Tracking apex marine predator movements in a dynamic ocean. Nature 475, 86-90. doi: 10.1038/nature 10082

Block, B. A., Teo, S. L. H., Walli, A., Boustany, A., Stokesbury, M. J. W., Farwell, C. J., et al. (2005). Electronic tagging and population structure of Atlantic Bluefin Tuna. Nature 434, 1121-1127. doi: 10.1038/nature03463

Bonfil, R., Meyer, M., Scholl, M. C., Johnson, R., O’Brien, S., Oosthuizen, H., et al. (2005). Transoceanic migration, spatial dynamics, and population linkages of white sharks. Science 310, 100-103. doi: 10.1126/science.1114898

Braccini, M., Aires-da-Silva, A., and Taylor, I. (2016). Incorporating movement in the modelling of shark and ray populations dynamics: approaches and management implications. Rev. Fish Biol. Fish. 26, 13-24. doi: 10.1007/s11160015-9406-x

Byrne, M. E., Cortés, E., Vaudo, J. J., Harvey, G. C. M. C. N., Sampson, M., Wetherbee, B. M., et al. (2017). Satellite telemetry reveals higher fishing mortality rates than previously estimated, suggesting overfishing of an apex marine predator. Proc. R. Soc. B 284:20170658. doi: 10.1098/rspb.2017. 0658 
Byrne, M. E., Vaudo, J. J., Harvey, G. C., Johnston, M. W., Wetherbee, B. M., and Shivji, M. (2019). Behavioral response of a mobile marine predator to environmental variables differs across ecoregions. Ecography 42, 1569-1578. doi: 10.1111/ecog.04463

Calenge, C. (2015). Home Range Estimation in R: The adehabitatHR Package. $R$ Package Version 0.3.23.

Campana, S. E. (2016). Transboundary movements, unmonitored fishing mortality, and ineffective international fisheries management pose risks for pelagic sharks in the Northwest Atlantic. Can. J. Aquat. Sci. 73:1599. doi: 10. 1139/cjfas-2015-0502

Campana, S. E., Joyce, W., Fowler, M., and Showell, M. (2016). Discards, hooking, and post-release mortality of the porbeagle (Lamna nasus), shortfin mako (Isurus oxyrinchus), and blue shark (Prionace glauca) in the Canadian pelagic longline fishery. ICES J. Mar. Sci. 73, 165-181. doi: 10.1093/icesjms/fsv234

Campana, S. E., Marks, L., and Joyce, W. (2005). The biology and fishery of shortfin mako sharks (Isurus oxyrinchus) in Atlantic Canadian waters. Fish. Res. 73, 341-352. doi: 10.1016/j.fishres.2005.01.009

Casey, J. G., and Kohler, N. E. (1992). Tagging studies on the shortfin mako shark (Isurus oxyrinchus) in the western North Atlantic. Mar. Freshw. Res. 43, 45-60. doi: $10.1071 / \mathrm{mf} 9920045$

Clarke, S. C., McAllister, M. K., Milner-Gulland, E. J., Kirkwood, G. P., Michielsens, C. G. J., Agnew, D. J., et al. (2006). Global estimates of shark catches using trade records from commercial markets. Ecol. Lett. 9, 1115-1126. doi: 10.1111/j.14610248.2006.00968.x

Compagno, L. J. V. (2001). Sharks of the World. An Annotated and Illustrated Catalogue of Shark Species Known to Date. Volume 2: Bullhead, Mackerel and Carpet Sharks (Heterodontiformes, Lamniformes and Orectolobiformes). FAO Species Catalogue for Fisheries Purposes No. 1, vol. 2. Rome: Food and Agriculture Organization of the United Nations.

Corrigan, S., Lowther, A. D., Beheregaray, L. B., and Bruce, B. D. (2018). Population connectivity of the mighly migratory Shortfin Mako (Isurus oxyrinchus Rafinesque 1810) and implications for management in the southern hemisphere. Front. Ecol. Evol. 6:187. doi: 10.3389/fevo.2018.00187

Cortés, E., Arocha, F., Beerkircher, L., Carvalho, F., Domingo, A., Heupel, M., et al. (2010). Ecological risk assessment of pelagic sharks caught in Atlantic pelagic longline fisheries. Aquat. Living Resour. 23, 402-410. doi: 10.1002/mcf2. 10029

Domeier, M. L., and Nasby-Lucas, N. (2013). Two-year migration of adult female white sharks (Carcharodon carcharias) reveals widely separated nursery areas and conservation concerns. Anim. Biotelemetry 1:2. doi: 10.1186/20503385-1-2

Dulvy, N. K., Fowler, S. L., Musick, J. A., Cavanagh, R. D., Kyne, P. M., Harrison, L. R., et al. (2014). Extinction risk and conservation of the world's sharks and rays. eLife 3:e00590. doi: 10.7554/eLife.00590

Estes, J. A., Terborg, J., Brashares, J. S., Power, M. E., Berger, J., Bond, W. J., et al. (2011). Trophic downgrading of Plant Earth. Science 333, 301-306.

Estrada, J. A., Rice, A. N., Lutcavage, M. E., and Skomal, G. B. (2003). Predicting trophic position in sharks of the north-west Atlantic Ocean using stable isotope analysis. J. Mar. Biol. Assoc. U.K. 83, 1947-1350.

Francis, M. P., Shivji, M. S., Duffy, C. A., Rogers, P. J., Byrne, M. E., Wetherbee, B. M., et al. (2019). Oceanic nomad or coastal resident? Behavioural switching in the shortfin mako shark (Isurus oxyrinchus). Mar. Biol. 166, 1-16. doi: 10. 1007/s00227-018-3453-5

Gibson, K. J., Streich, M. K., Topping, T. S., and Stunz, G. W. (2019). Utility of citizen science data: a case study in land-based shark fishing. PLoS One 14:e0226782. doi: 10.1371/journal.pone.0226782

Hammerschlag, N., Schmitz, O. J., Flecker, A. S., Lafferty, K. D., Sih, A., Atwood, T. B., et al. (2019). Ecosystem function and services of aquatic predators in the Anthropocene. Trends Ecol. Evol. 34, 369-383. doi: 10.1016/j.tree.2019.01.005

Hays, G. C., Bailey, H., Bograd, S. J., Bowen, W. D., Campagna, C., Carmichael, R. H., et al. (2019). Translating marine animal tracking data into conservation policy and management. Trends Ecol. Evol. 34, 459-473.

Heist, E. J., Musick, J. A., and Graves, J. E. (1996). Genetic population structure of the shortfin mako (Isurus oxyrinchus) inferred from restriction fragment length polymorphism analysis of mitochondrial DNA. Can. J. Aquat. Sci. 53, 583-588. doi: 10.1139/f95-245

Holts, D. B., Julian, A., Sosa-Nishizaki, O., and Bartoo, N. W. (1998). "Pelagic shark fisheries along the west coast of the United States and Baja California,
Mexico," in Proceedings of an International Symposium Held at the 125th Annual Meeting of the American Fisheries Society, ed. R. E. Hueter (Tampa, FL: Fish. Res.), 115-125. doi: 10.1016/s0165-7836(98)00178-7

Hoolihan, J. P., Wells, R. J. D., Luo, J., Faltherman, B., Prince, E. D., and Rooker, J. R. (2014). Vertical and horizontal movements of yellowfin tuna in the Gulf of Mexico. Mar. Coast. Fish. 6:211. doi: 10.1080/19425120.2014.935900

International Commission for the Conservation of Atlantic Tunas [ICCAT] (2013). Report of the 2012 shortfin mako stock assessment and ecological risk assessment meeting. Collective Volume of Scientific Papers ICCAT. Madrid: ICCAT, 14271570 .

International Commission for the Conservation of Atlantic Tunas [ICCAT] (2017). Report of the Standing Committee on Research and Statistics (SCRS). 2017 SCRS Report ICCAT. Madrid: ICCAT.

International Commission for the Conservation of Atlantic Tunas [ICCAT] (2019). "Report of the 2019 shortfin mako sharks stock assessment update meeting," in Proceedings of the SMA SHRK SA Intersessional Meeting, Madrid.

International Commission for the Conservation of Atlantic Tunas [ICCAT] (2020). Shark Check Sheets Received in Accordance with REC. 18-06. COC_314/2020. Madrid: ICCAT.

Jonsen, I. D., Flemming, J. M., and Myers, R. A. (2005). Robust state-space modeling of animal movement data. Ecology 86, 2874-2880. doi: 10.1890/041852

Jonsen, I. D., Myers, R. A., and James, M. C. (2007). Identifying leatherback turtle foraging behavior from satellite telemetry using a switching state-space model. Mar. Ecol. 337, 255-264. doi: 10.3354/meps337255

Jorgensen, S. J., Reeb, C. A., Chapple, T. K., Anderson, S., Perle, C., Van Sommeran, S. R., et al. (2010). Philopatry and migration of Pacific white sharks. Proc. R. Soc. B 277, 679-688. doi: 10.1098/rspb.2009.1155

JPL OurOcean Project (2010). G1SST L4 SST Analysis. Ver. 1. PO.DAAC, CA, USA. Available online at: https://doi.org/10.5067/GHG1S-4FP01 (accessed December 01, 2020).

Kohler, N. E., Turner, P. A., Hoey, J. J., Natanson, L. J., and Briggs, R. (2002). Tag and recapture data for three pelagic shark species: blue shark (Prionace glauca), shortfin mako (Isurus oxyrinchus), and porbeagle (Lamna nasus) in the North Atlantic Ocean. Collect. Volumes Sci. Pap. ICCAT 54, 1231-1260.

Kraus, R. T., Wells, R. J. D., and Rooker, J. R. (2011). Horizontal movements of Atlantic blue marlin (Makaira nigricans) in the Gulf of Mexico. Mar. Biol. 158, 699-713. doi: 10.1007/s00227-010-1593-3

Lea, J. S. E., Wetherbee, B. M., Queiroz, N., Burnie, N., Aming, C., Sousa, L. L., et al. (2015). Repeated, long-distance migrations by a philopatric predator targeting highly contrasting ecosystems. Sci. Rep. 5:11202. doi: 10.1038/srep11202

Loefer, J. K., Sedberry, G. R., and McGovern, J. C. (2005). Vertical movement of a shortfin mako in the western North Atlantic as determined by pop-up satellite tagging. Southeast. Nat. 4, 237-246. doi: 10.1656/1528-7092(2005)004[0237: vmoasm]2.0.co;2

Longhurst, A. (2007). Ecological Geography of the Sea, 2nd Edn. Burlington, MA: Academic Press.

Magurran, A. E., and Seghers, B. H. (1994). A cost of sexual harassment in the guppy, Poecilia reticulata. Proc. R. Soc. B 258, 89-92. doi: 10.1098/rspb.1994. 0147

Mollet, H. F., Cliff, G., Pratt, H. L. Jr., and Stevens, J. D. (2000). Reproductive biology of the female shortfin mako, Isurus oxyrinchus Rafinesque, 1810, with comments on the embryonic development of lamnoids. Fish. Bull. 98, 299-318.

Mucientes, G. R., Queiroz, N., Sousa, L. L., Tarroso, P., and Sims, D. W. (2009). Sexual segregation of pelagic sharks and the potential threat from fisheries. Biol. Lett. 5, 156-159. doi: 10.1098/rsbl.2008.0761

Musyl, M. K., Brill, R. W., Curran, D. S., Fragoso, N. M., McNaughton, L. M., Nielsen, A., et al. (2011). Post-release survival, vertical and horizontal movements, and thermal habitats of five species of pelagic sharks in the central Pacific Ocean. Fish. Bull. 109, 341-368.

Nasby-Lucas, N., Dewar, H., Sosa-Nishizaki, C., Wilson, C., Hyde, J. R., Vetter, R. D., et al. (2019). Movements of electronically tagged shortfin mako sharks (Isurus oxyrinchus) in the eastern North Pacific Ocean. Anim. Biotelemetry 7:12. doi: 10.1186/s40317-019-0147-6

Natanson, L. J., Winton, M., Bowlby, H., Joyce, W., Deacy, B., Coelho, R., et al. (2020). Updated reproductive parameters for the shortfin mako (Isurus oxyrinchus) in the North Atlantic Ocean with inferences of distribution by sex and reproductive stage. Fish. Bull. 118, 21-36. doi: 10.7755/FB.118.1.3 
Pante, E., and Simon-Bouhet, B. (2013). Marmap: a package for importing, plotting and analyzing bathymetric and topographic data in R. PLoS One 8:e0073051. doi: 10.1371/journal.pone.0073051

Pratt, H. L. Jr., and Casey, J. G. (1983). Age and growth of the shortfin mako, Isurus oxyrinchus, using four methods. Can. J. Aquat. Sci. 40, 1944-1957. doi: 10.1139/f83-224

Queiroz, N., Humphries, N. E., Mucientes, G., Hammerschlag, N., Lima, F. P., Scales, K. L., et al. (2016). Ocean-wide tracking of pelagic sharks reveals extent of overlap with longline fishing hotspots. PNAS 113, 1582-1587. doi: 10.1073/ pnas. 1510090113

Queiroz, N., Humphries, N. E., Couto, A., Vedor, M., da Costa, I., and Sequeira, A. M. M. (2019). Global spatial risk assessment of sharks under the footprint of fisheries. Nature 572, 461-466. doi: 10.1038/s41586-019-1444-4

R Core Team (2014). R: A Language and Environment for Statistical Computing. Vienna: $\mathrm{R}$ foundation for statistical computing.

Ricker, W. E. (1981). Changes in the average size and age of Pacific Salmon. Can. J. Aquat. Sci. 38, 1636-1656. doi: 10.1139/f81-213

Rigby, C. L., Barreto, R., Carlson, J., Fernando, D., Fordham, S., Francis, M. P., et al. (2018). Isurus Oxyrinchus. The IUCN Red List of Threatened Species 2019. Available online at: http://dx.doi.org/10.2305/IUCN.UK.2019-1.RLTS. T39341A2903170.en (accessed September 06, 2019).

Rogers, P. J., Huveneers, C., Page, B., Goldsworthy, S. D., Coyne, M., Lowther, A. D., et al. (2015). Living on the continental shelf edge: habitat use of juvenile shortfin mako sharks Isurus oxyrinchus in the Great Australian Bight, southern Australia. Fish. Oceanogr. 24, 205-218. doi: 10.1111/fog. 12103

Rooker, J. R., Dance, M. A., Wells, R. J. D., Ajemian, M. J., Block, B. A., Castleton, M. R., et al. (2019). Population connectivity of pelagic megafauna in the Cuba-Mexico-United States triangle. Sci. Rep. 9:1663. doi: 10.1038/s41598-01838144-8

Santos, C. C., Domingo, A., Carlson, J., Natanson, L. J., Cortés, E., Miller, P., et al. (2018). Habitat use and migrations of shortfin mako in the Atlantic using satellite telemetry. Collect. Volumes Sci. Pap. ICCAT 73, 445-456.

Schrey, A. W., and Heist, E. J. (2003). Microsatellite analysis of population structure in the shortfin mako (Isurus oxyrinchus). Can. J. Aquat. Sci. 60, 670-675. doi: 10.1137/F03-064

Sequeira, A. M. M., Rodriguez, J. P., Eguiluz, V. M., Harcourt, R., Hindell, M., Sims, D. W., et al. (2018). Convergence of marine megafauna movement patterns in coastal and open oceans. Proc. Natl. Acad. Sci. U.S.A. 115, 3072-3077. doi: 10.1073/pnas.1716137115

Simpfendorfer, C. A., Olsen, E. M., Heupel, M. R., and Moland, E. (2012). Three-dimensional kernel utilization distributions improve estimates of space use in aquatic animals. Can. J. Aquat. Sci. 69, 1660-1680. doi: 10.1139/ f2011-179

Sims, D. W., Mucientes, G., and Queiroz, N. (2018). Shortfin mako sharks threatened by inaction. Science 359:1342.

Sippel, T., Ohshimo, S., Yokawa, K., Kai, M., Carvalho, F., Liu, K. M., et al. (2015). Spatial and Temporal Patterns of Shortfin Mako Shark Size and Sex in the North Pacific Ocean. ISC/15/SHARKWG-1/04. Copenhagen: ICES.

Smith, P. J., Francis, R. I. C. C., and McVeagh, M. (1991). Loss of genetic diversity due to fishing pressure. Fish. Res. 10, 309-316. doi: 10.1016/0165-7836(91) 90082-q

Stevens, J. D. (1974). The occurrence and significance of tooth cuts on the blue shark (Prionace glauca L.) from British waters. J. Mar. Biol. Assoc. U.K. 54, 373-378. doi: 10.1017/S0025315400058604

Stillwell, C. E., and Kohler, N. E. (1982). Food, feeding habits, and estimates of daily ration of the shortfin mako (Isurus oxyrinchus) in the northwest Atlantic. Can. J. Aquat. Sci. 39, 407-414. doi: 10.1139/f82-058

Vaudo, J. J., Byrne, M. E., Wetherbee, B. M., Harvey, G. M., and Shivji, M. S. (2017). Long-term satellite tracking reveals region-specific movements of a large pelagic predator, the shortfin mako shark, in the western North Atlantic Ocean. J. Appl. Ecol. 54, 1765-1775. doi: 10.1111/1365-2664.12852

Vaudo, J. J., Wetherbee, B. M., Wood, A. D., Weng, K., Howey-Jordan, L. A., Harvey, G. M., et al. (2016). Vertical movements of shortfin mako sharks Isurus oxyrinchus in the western North Atlantic Ocean are strongly influenced by temperature. Mar. Ecol. Prog. Ser. 547, 163-175. doi: 10.3354/meps11646

Waples, R. S. (1998). Separating the wheat from the chaff - patterns of genetic differentiation in high gene flow species. J. Hered. 89, 438-450. doi: 10.1093/ jhered/89.5.438

Wood, A. D., Wetherbee, B. M., Juanes, F., Kohler, N. E., and Wilga, C. (2009). Recalculated diet and daily ration of the shortfin mako (Isurus oxyrinchus), with a focus on quantifying predation on bluefish (Pomatomus saltatrix) in the northwest Atlantic Ocean. Fish. Bull. 107, 76-88.

Conflict of Interest: The authors declare that the research was conducted in the absence of any commercial or financial relationships that could be construed as a potential conflict of interest.

Copyright (C) 2021 Gibson, Streich, Topping and Stunz. This is an open-access article distributed under the terms of the Creative Commons Attribution License (CC BY). The use, distribution or reproduction in other forums is permitted, provided the original author(s) and the copyright owner(s) are credited and that the original publication in this journal is cited, in accordance with accepted academic practice. No use, distribution or reproduction is permitted which does not comply with these terms. 